\footnotetext{
${ }^{1}$ AGROKOMPLEX C.S. RT., Company of Provimi, Hungary

${ }^{2}$ University of Kaposvár, Faculty of Animal Science, Hungary
}

\title{
Tracking the development of serum biochemical parameters in two laying hen strains - a comparative study
}

\begin{abstract}
A follow-up, comparative study was designed for the description of differences between two divergent laying hen strains, a Leghorn type and a medium heavy body (MHB) genotype (Hy-Line Brown), in chemical body composition and serum biochemical parameters determined at 3, 4, 6, 8, 10,12, 14, 18, 20, 25, 30, 52 and 72 weeks of age; each time 5 birds of both genotypes were analysed and exterminated for body composition analysis.

Resulting from the genotype-associated differences, the bodyweight of the populations differed from week 20 on. In the chemical body composition dry matter content was similar, while crude protein was higher on weeks $3,8,10$, and after 18 weeks in the Leghorns. Crude fat content was higher in the brown birds (weeks 8, 10, 25, 30). Total serum protein and albumin showed slightly increasing trends, while serum creatinine concentration showed a downward trend in both genotypes, the MHB birds having higher values. Triglyceride concentration showed a drastic step-up at 17 weeks by changing to the pre-layer diet, coupled with marked between-genotype differences. This quick increase was matched by concentration drops in total and HDL cholesterol, the serum HDL cholesterol of Leghorns being always lower. Sodium concentration showed an increasing tendency with body $\mathrm{DM}$ content $\left(\mathrm{R}^{2}=0.914, \mathrm{P}<0.001, \mathrm{n}=115\right)$. The Leghorns tended to show minimally higher $\mathrm{Ca}$ concentrations. The $\gamma$-GT activity was always higher in MHB birds, indicating a less effective hepatic adaptation to the peak production. Applying discriminant analysis to classify the genotypes, $94.4 \%$ of the original grouped cases was correctly classified, using all variables.
\end{abstract}

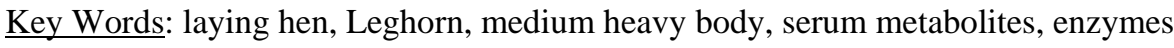

\section{Zusammenfassung}

Titel der Arbeit: Verlaufsuntersuchung biochemischer Blutparameter bei zwei Leghorn Genotypen Vergleichsstudie

Es erfolgte ein Vergleich von zwei Leghorn Genotypen (Hy-Line W-98-Leghorntyp und Hy-Line Brown Medium heavy body type, MHB). Untersucht wurden die Ganzkörperzusammensetzung und biochemische Blutparameter von der 3. bis zur 72. Woche bei jeweils fünf Tieren je Genotyp. Ab der 20. Lebenswoche wurden größere Körpergewichte der MHB Tiere nachgewiesen. Bei der chemischen Körperzusammensetzung entwickelte sich der Trockensubstanzgehalt und der Aschegehalt in beiden Populationen ähnlich. Der Proteingehalt bei den Leghorntypen war in allen Lebenswochen höher und bei den MHB Genotypen lag in der 3., 8., und 10. Woche der Fettgehalt im Gesamtkörper höher. Bei den Blutserumwerten wurde ein leichter Anstieg der Serumprotein- und Albumingehalte jedoch ein Abfall der Kreatininkonzentration in beiden Populationen beobachtet, wobei jedoch die mittelschweren MHB Typen höhere Werte erreichten. Nach der in der 17. Woche erfolgten Umstellung auf Legefutter war in beiden Genotypen ein unterschiedlicher aber erheblicher Anstieg der Serumtriglyceridkonzentration zu beobachten. Diese Erhöhung war von einem abnehmenden Trend der Gesamt- und HDL-Konzentration begleitet, wobei diese Abnahme besonders bei HDL auftrat. Die Natriumkonzentration erhöhte sich analog zum Aschegehalt des Gesamtkörpers. Die Kalziumkonzentration war höher bei den Leghorngenotypen, während die $\gamma$-GT Aktivität bei den MHB Tieren höher war, was bei ihnen auf eine geringere hepatitische Anpassungsfähigkeit während der Produktionsspitze hindeutet. Beide Genotypen konnten mit Hilfe der Diskriminanzanalyse bei Einbeziehung aller Variablen mit einer Genauigkeit von $94,4 \%$ bewertet werden.

Schlüsselwörter: Legehennen, Leghorn, mittelschwer, Serummetabolite, Enzyme 


\section{Introduction}

Specific selection for egg production and body size led to the establishment of numerous lines of laying-type hens, applied widespread in the table egg production. The background of the genetic development of divergent layer lines is highly complex, including factors like production level, product quality (shell colour), consumer demands, as well as economic weights (MUIR, 2003). Taking multiple conditions into account by the selection decisions, the long lasting breeding progress led to the establishment of basically different layer genotypes.

There exists a robust knowledge on the production (GARLICH et al., 1984), keeping (NURGIARTININGSIH et al., 2002; MIELENZ et al., 2005; STRUELENS et al., 2005), nutrition (CROSS et al., 1987; SUCHY et al., 1997; DURMUS et al., 2004), behavioural (MACHAL and JERABEK, 2000; RODENBURG et al., 2004) or body compositional (ROMVÁRI et al., 2005) characteristics of divergent layer lines. However, comparative studies are mainly performed to test the improvement, reached in genetics, health (resistence), production environment, molting, morphological alterations, handling during depopulation, transportation, and harvesting, nowadays more and more including also animal welfare aspects (MACHAL et al., 1994; HESTER, 2005). Accordingly, comparative studies rather focus on the improvement or actualization (i.e. taking novel regulations into account) of the conditions of egg production.

In contrast, basic metabolic investigations, elucidating the differences standing in the background of all the above-mentioned factors are less often published. Although table egg production, and its physiological and metabolic aspects are very widely and deeply investigated, these studies are generally strongly specific, focusing mainly on a pre-defined, single, mainly production-physiological factor (MACHAL et al., 1994; SUCHY et al., 1997; MACHAL and JERABEK, 2000; STRAKOVA et al., 2001).

The aim of this study was to compare two, basically different layer genotypes, in the frame of a longitudinal study, based on serum biochemical parameters. This methodology allowed to compare the entire developmental process of the metabolic characteristics of the to bird types. This experimental setting was, finally, an approach to support the production differences by the metabolic background, and the differences of it.

\section{Materials and methods}

Experimental birds, housing, feeding

Hy-Line W-98 (Leghorn type) and Hy-Line Brown (Medium heavy body type, MHB) laying hens were applied in the study, from the $1^{\text {st }}$ day of life until 72 weeks of age.

The experiment took place at the experimental poultry farm of the University of Kaposvár, Faculty of Animal Science. The stock was bred from the day-old age till placing them to the layer house, at the age of 18 weeks, onto litter, in an airconditioned building with controlled experimental conditions and lighting. The feeding regime applied is given in detail in Table 1.

\section{Blood sampling and analysis}

Blood samples from the left $v$. brachialis were taken from each 5 birds/genotype at the age of 3, 4, 6, 8, 10, 12, 14, 18, 20, 25, 30, 52 and 72 weeks, in a longitudinal study. After withdrawal, blood was immediately cooled on ice, centrifuged (5000 rpm, 10 
min) and serum was decanted. Serum metabolites and enzyme activities were measured on a Konelab 20i ${ }^{\circledR}$ apparatus (Thermo Electron Corp., Espoo, Finland), using original Konelab ${ }^{\circledR}$ Reagent Kits. Total serum protein, albumin, creatinine, uric acid, triacylglycerol, total- and HDL-cholesterol, $\mathrm{Ca}, \mathrm{K}, \mathrm{Na}$, inorganic phosphorus concentrations, and amylase (AMYL), alkaline phosphatase (ALP), creatine kinase (CK) and basal total lactate dehydrogenase (LDH) activities were determined.

At all these timepoints each five (the sampled) birds were experimentally slaughtered, for detailed chemical body composition analysis.

The trial was approved by the Animal Experimentation Ethics Committee of the University of Kaposvár.

Table 1

Feeding regime and feed composition during the study (Fütterung und Futterzusammensetzung im Experiment)

\begin{tabular}{|c|c|c|c|c|c|}
\hline Feed type & $\begin{array}{c}\text { Chicken starter } \\
\text { feed }\end{array}$ & $\begin{array}{c}\text { Pullet grower } \\
\text { feed }\end{array}$ & $\begin{array}{c}\text { Pre-layer } \\
\text { feed }\end{array}$ & Layer feed & $\begin{array}{l}\text { After peak } \\
\text { layer feed }\end{array}$ \\
\hline Feeding interval (weeks) & $0-6$ & $7-16$ & 17-18 & $19-$ & $85 \%>$ \\
\hline \multicolumn{6}{|l|}{ Ingredients } \\
\hline Corn (\%) & 54.6 & 49.5 & 59.3 & 48.8 & 54.3 \\
\hline Wheat (\%) & 10.0 & 20.0 & 10.0 & 10.0 & 10.0 \\
\hline Soybean 48 (\%) & 26.5 & 12.5 & 14.5 & 11.0 & 8.5 \\
\hline Fishmeal 70 (\%) & - & - & - & 2.0 & 2.0 \\
\hline Full-fat soy (\%) & - & - & - & 3.0 & - \\
\hline Sunflower meal (\%) & 5.0 & 5.5 & 7.0 & 7.0 & 7.0 \\
\hline Wheat powder (\%) & - & 6.5 & - & - & - \\
\hline Alflafa meal (\%) & - & 2.5 & 2.5 & 3.0 & 3.0 \\
\hline Corn gluten (\%) & - & - & - & 2.0 & 3.0 \\
\hline \multirow[t]{2}{*}{ Premix (\%) } & 3.9 & 3.5 & 6.7 & 13.2 & 12.2 \\
\hline & 100.0 & 100.0 & 100.0 & 100.0 & 100.0 \\
\hline \multicolumn{6}{|l|}{ Nutrient levels } \\
\hline Dry matter \% & 88.5 & 88.5 & 88.5 & 88.5 & 88.5 \\
\hline Crude protein (\% DM) & 22.7 & 17.5 & 18.5 & 19.8 & 18.9 \\
\hline Ether extract (\% DM) & 3.3 & 3.4 & 3.3 & 3.8 & 3.3 \\
\hline Crude fiber (\% DM) & 3.5 & 4.5 & 4.0 & 4.1 & 3.9 \\
\hline Crude ash (\% DM) & 7.3 & 6.8 & 10.2 & 16.2 & 16.0 \\
\hline ME (MJ/kg DM) & 13.9 & 13.4 & 13.4 & 13.0 & 12.9 \\
\hline Ca (g/kg DM) & 11.6 & 10.5 & 23.3 & 45.3 & 4.5 \\
\hline P (g/kg DM) & 7.2 & 6.2 & 6.9 & 7.3 & 7.1 \\
\hline Mg (g/kg DM) & 0.0 & 1.0 & 0.1 & 0.3 & 0.3 \\
\hline K (g/kg DM) & 9.2 & 5.9 & 7.0 & 6.7 & 5.8 \\
\hline Na (g/kg DM) & 1.7 & 1.7 & 1.7 & 1.8 & 1.8 \\
\hline $\mathrm{Mn}(\mathrm{mg} / \mathrm{kg} \mathrm{DM})$ & 84.4 & 78.2 & 70.6 & 70.7 & 70.7 \\
\hline Cu (mg/kg DM) & 6.2 & 5.8 & 5.2 & 5.3 & 5.3 \\
\hline Zn (mg/kg DM) & 84.4 & 78.3 & 70.7 & 70.8 & 70.8 \\
\hline $\mathrm{Fe}(\mathrm{mg} / \mathrm{kg} \mathrm{DM})$ & 61.7 & 70.2 & 52.6 & 55.1 & 55.1 \\
\hline
\end{tabular}

Body composition analysis

Birds undergoing blood sampling were exterminated immediately after this, and the chemical composition of the total body was determined by direct chemical analysis after homogenization. Dry matter (DM) content was determined by drying the sample at $105{ }^{\circ} \mathrm{C}$ to constant weight. Crude fat (CF) content was determined by ether extraction. Hydrochloride acid digestion and a Kjel-Foss Fast Nitrogen Analyzer was 
used for the determination of the nitrogen content; crude protein (CP) content was obtained by multiplying data with 6.25 . Ash content was determined by heating the samples in muffle furnace to constant weight at $500{ }^{\circ} \mathrm{C}$.

\section{Statistical analysis}

Serum parameters of the two genotypes were compared at every sampling event (5 Leghorn vs. $5 \mathrm{MHB}$ ), using multivariate analysis of variance. Analysing the independent variables, the age and genotype were treated as fixed factors, while bodyweight was a covariant in the model. The classification of the two genotypes was performed by discriminant analysis, entering all blood parameters at all samplings into the model. Pairwise correlations were calculated by the Pearson method, on the entire dataset. The level of statistical significance was set to $\mathrm{P}<0.05$. SPSS 10 for Windows (1999) was used for the analysis.

\section{Results}

As a result of the basic genotype-associated differences, the bodyweight of the two layer populations (Leghorn and medium heavy body) was significantly different from week 20 on $(\mathrm{P}<0.001)$ (Fig. 1). Similarly, general differences were found in some important blood biochemical parameters. Interestingly, the fixed factors of the statistical model were found to interact in most of the cases.

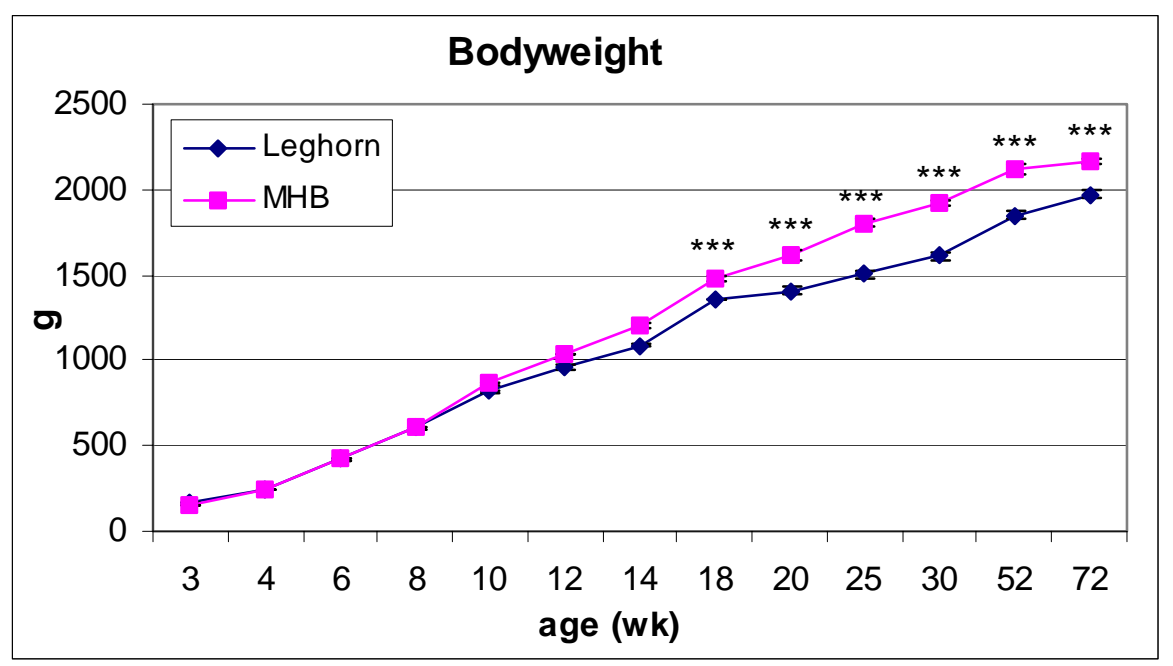

Fig. 1: Alterations of the bodyweight in the two genotypes along the trial (each point represents a mean of 5 ind. data \pm SD) (Änderung des Lebendgewichtes der zwei Genotypen während des Experiments; einzelne Punkte zeigen Mittelwerte \pm Standardabweichung von je 5 Vögeln)

\section{Chemical body composition}

Age-associated alterations in the chemical body composition are summarized in Figure 2.

The dry matter of the total body showed an increasing trend with aging, and the medium heavy birds tended to show minimally higher values, significance was proven on weeks 3, 6 and 30. The crude protein content was, however, rather different between the two populations, the Leghorns providing statistically higher values on weeks 3, 8, 10, 18 and continuously until the period investigated. In contrast, the crude fat content was higher in the brown birds, with significant advantage on weeks 8,10 , 25 and 30. The crude ash content was only different between the genotypes at the start 
of the experiment (weeks 3 and 4) and at the very end, the medium heavy body birds showing higher values.

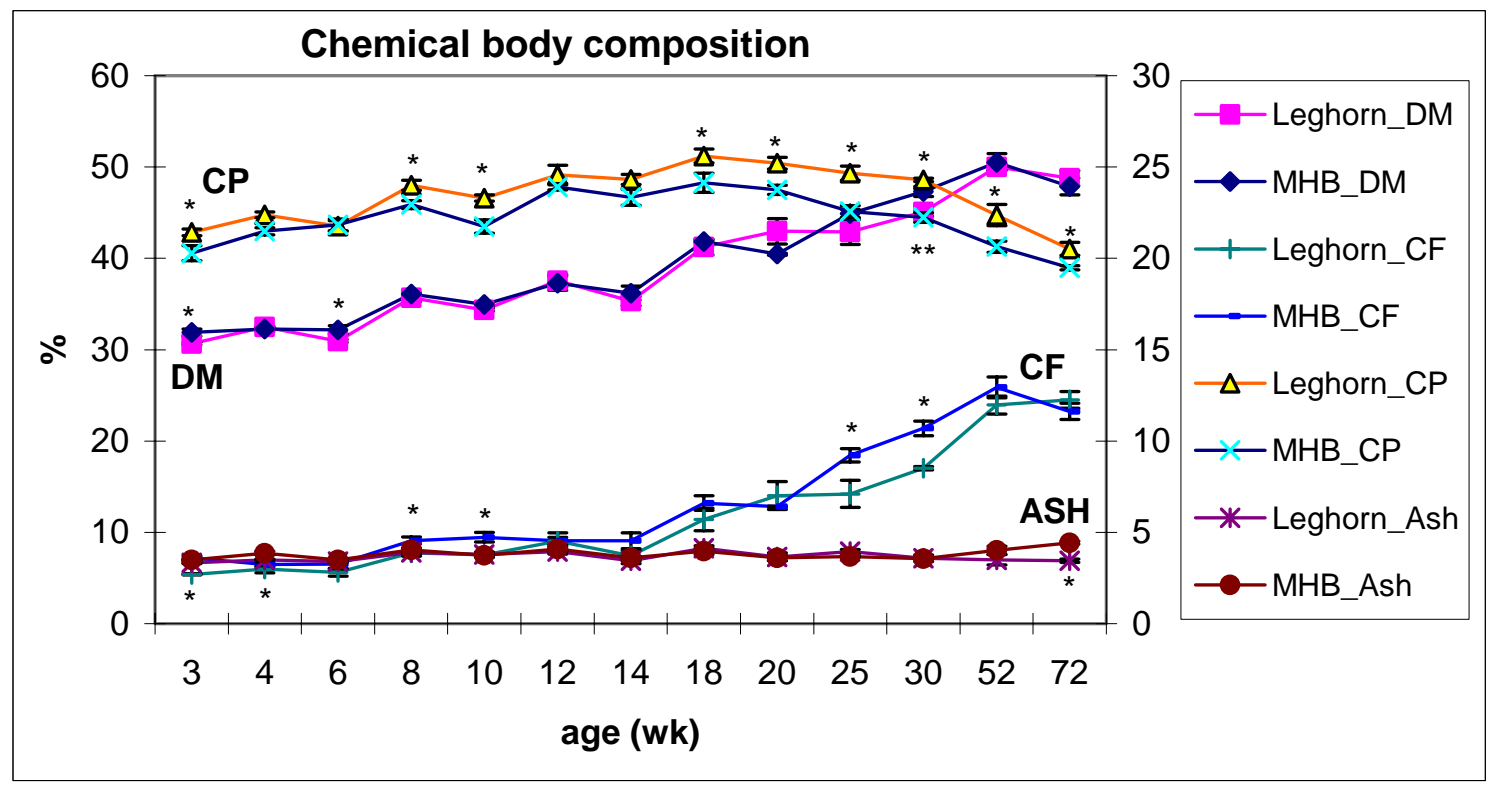

Fig. 2: Changes in the chemical body composition during the experimental period, mean \pm SD (Änderungen der chemischen Körperzusammensetzung während der Untersuchung)

\section{Serum metabolites and ions}

Along the experiment, from the nitrogenous constituents, total serum protein and albumin showed slightly increasing trends, both with three, less pronounced concentration peaks, at the ages of 6,14 and 31 weeks (Fig. 3).

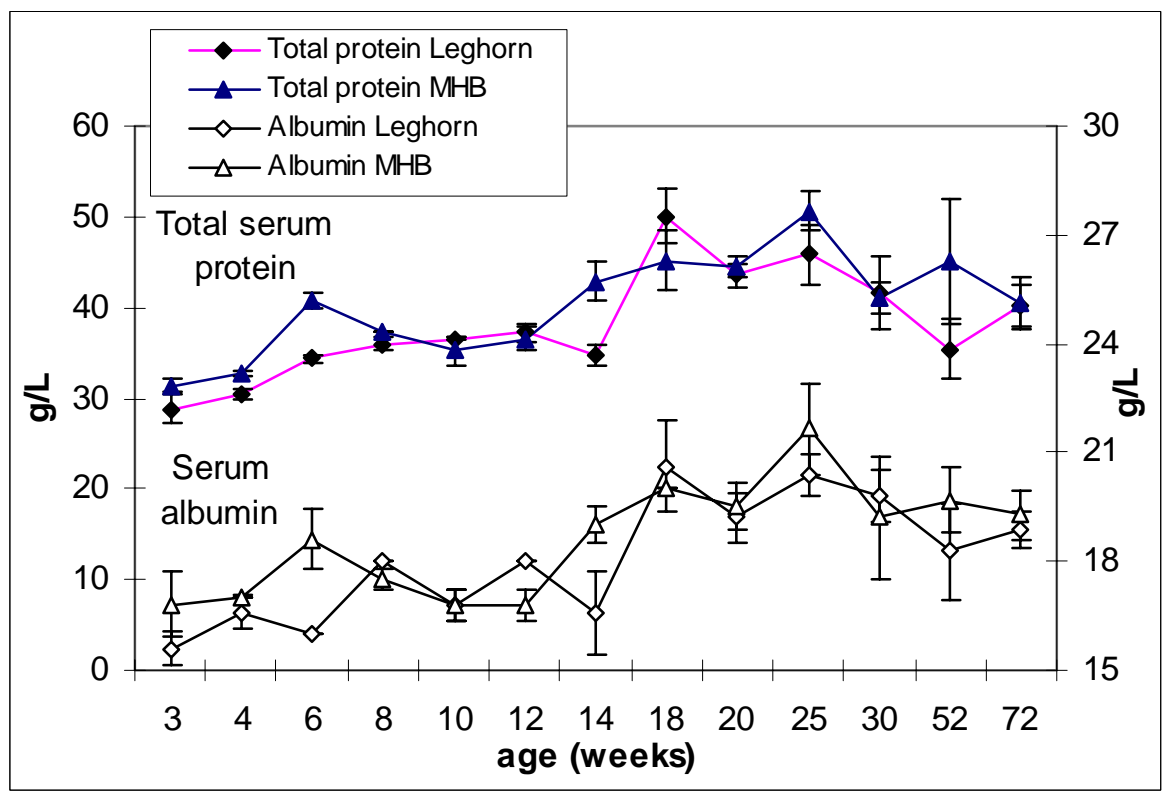

Fig. 3: Total serum protein and albumin concentrations of the two genotypes during the trial (Serumprotein- und Albumingehalt der zwei Genotypen)

Moreover, serum creatinine concentration showed a downward trend in both genotypes, the medium heavy body (MHB) type birds always showing higher values (Fig. 4.). The above-mentioned three concentration peaks were clearly recorded as 
well for creatinine, at identical ages. The first and last peaks were paralleled by less important, but detectable concentration peaks as well for urate, the Leghorn type tending to possess higher values, although the between-genotype difference was only significant on weeks 3 and $25(\mathrm{P}<0.001)$. The urate concentrations were relatively balanced, ranging between 200 and $300 \mu \mathrm{mol} / \mathrm{L}$.

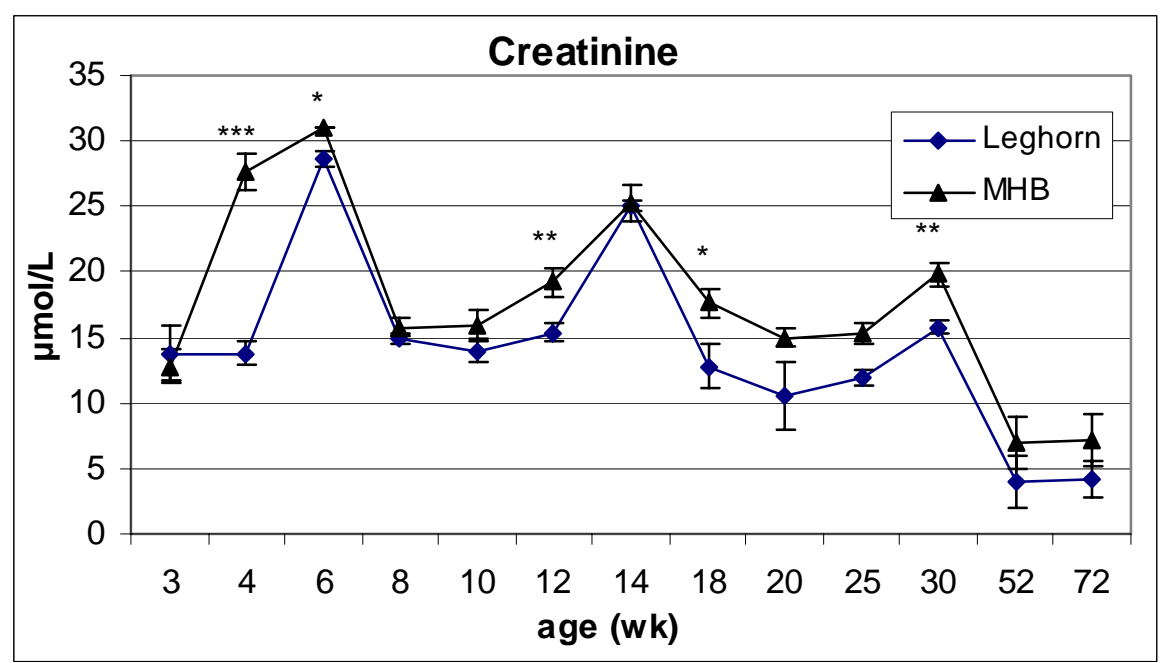

Fig. 4: The alterations in the serum creatinine concentrations during the trial (Änderungen der Kreatininkonzentration)

In the lipid metabolites, for the triglyceride concentration a drastic step-up was detected from the age of 17 weeks by changing the diets to layer type (Fig. 5). Between-genotype differences were proven during the step-up (weeks 18 and 20), and at the age of 72 weeks. The initial quick increase was furthermore paired with a slight concentration drop in total cholesterol, while a marked decrease was found for the HDL cholesterol levels, in both genotypes. In addition, the serum HDL cholesterol levels of the Leghorns were always lower than those of the medium heavy types, though significance was only proven in the initial phase and by the step-up (Fig. 6).

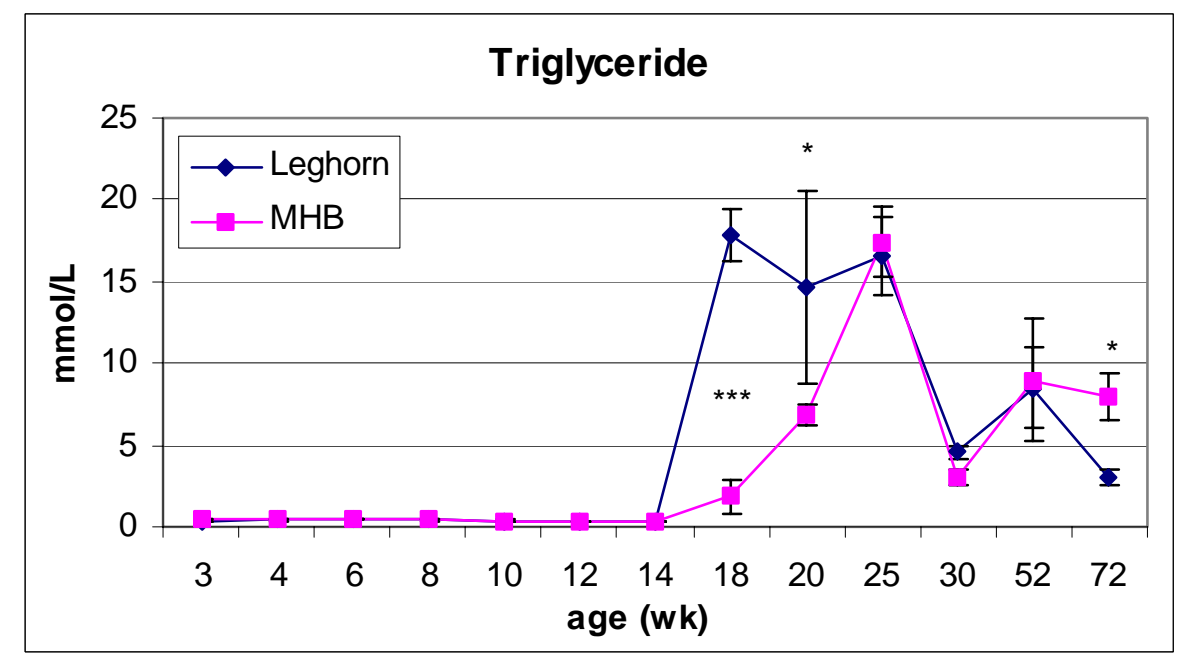

Fig. 5: Fluctuations of the serum triglyceride concrentrations along the trial (Schwankungen der Triglyceridkonzentration) 


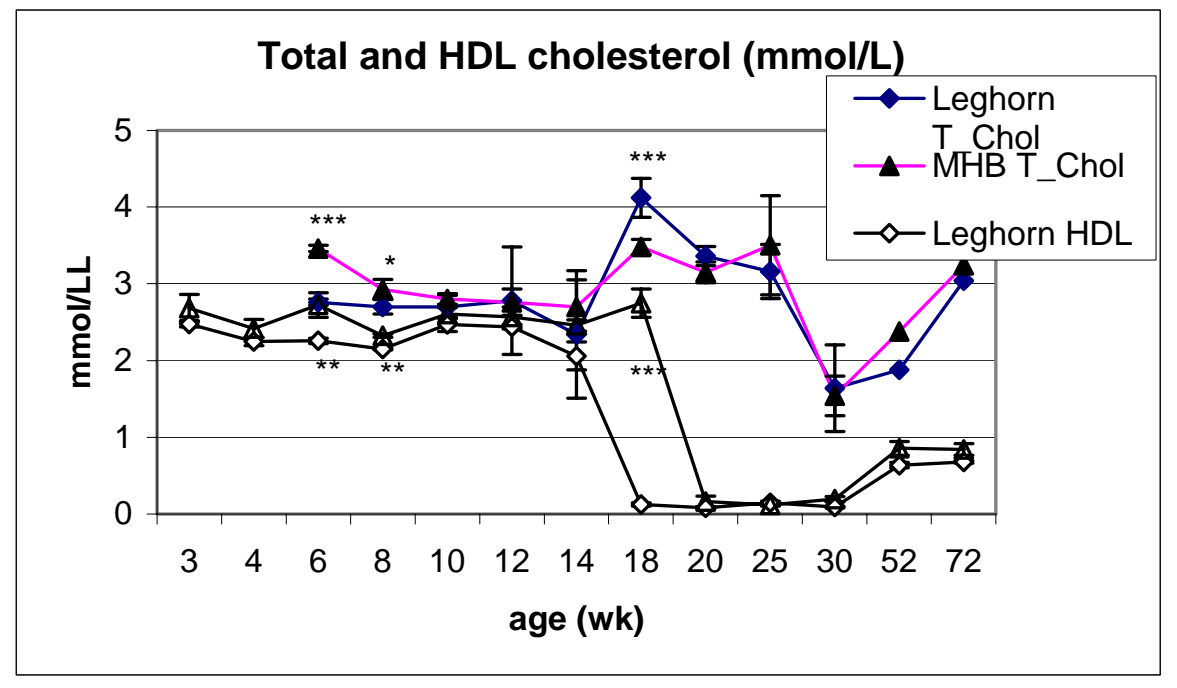

Fig. 6: The total and HDL cholesterol concentrations in the studied interval (Die Gesamt- und HDLCholesterinkonzentration)

In the serum ion concentrations the sodium $(\mathrm{Na})$ concentration showed a clearly increasing tendency with the age (Fig. 7.) and was paralleled by the increase of the total body dry matter content. The correlation coefficient between these two variables was $0.914(\mathrm{P}<0.001, \mathrm{n}=115)$.

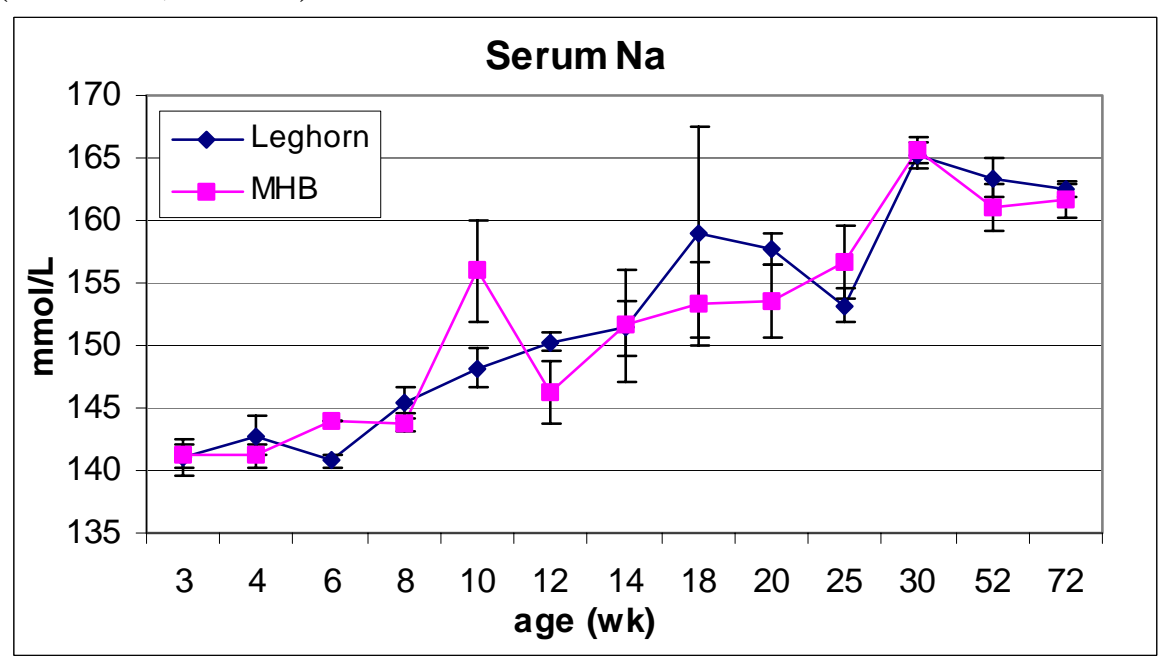

Fig. 7: Changes of the serum sodium concentration along the study (Änderungen der Natriumkonzentration)

The serum calcium concentration was relatively balanced until the start of the laying period, fluctuating between 2 and $3 \mathrm{mmol} / \mathrm{L}$. By changing to the layer diet, and in the intensification of the egg production a rather intensive (ca. threefold) increase was experienced. The Leghorns tended to show minimally higher concentration values, though significance was only proven on week $30(\mathrm{P}<0.01, \mathrm{n}=10)$. The inorganic phosphorus concentration, before and also in the laying period was found to be relatively balanced in both genotypes. The serum potassium concentration ranged from 4 to $6 \mathrm{mmol} / \mathrm{L}$ during the entire 72 weeks, the medium heavy type birds tending to have slightly higher values, without significance. 


\section{Serum enzymes}

The enzymatic processes were also characteristic along the study. Focusing on the liver, the $\gamma$-glutamyl trasferase $(\gamma$-GT) activity was found always to be lower in the Leghorn type birds and significant difference was proven only on weeks 3, 12, 14 and 18. The alkaline phosphatase enzyme activity was not different between genotypes during the study, although a downward process was shown during the entire production period (Fig. 8).

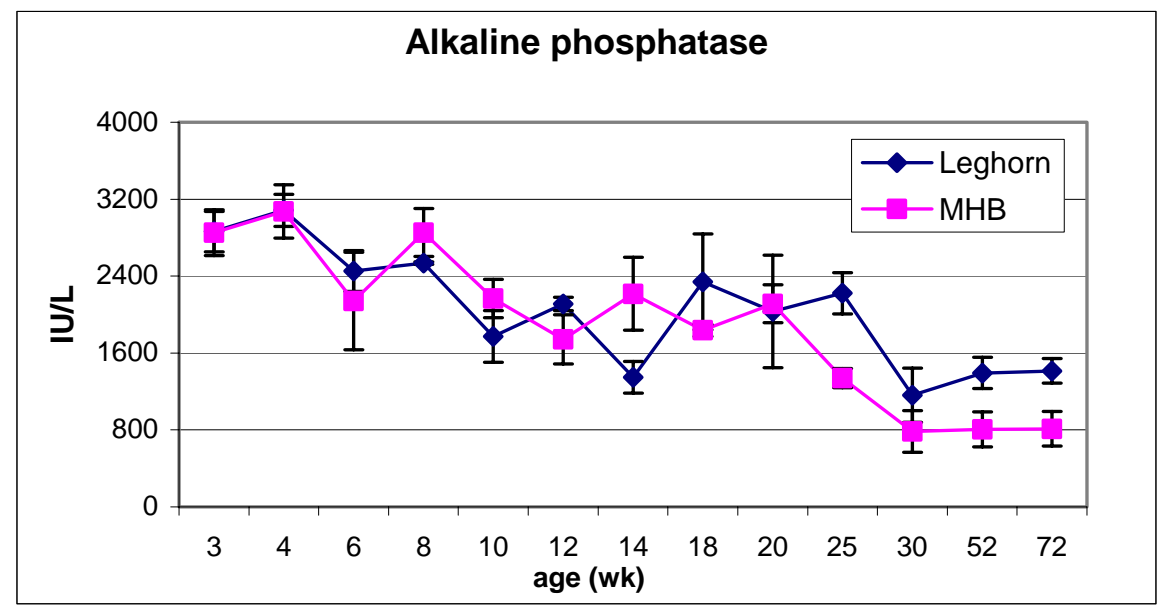

Fig. 8: The downward activity trend detected for alkaline phosphatase in both genotypes (Der Aktivitätsnachlass von alkalischer Phosphatase)

The lactate dehydrogenase ( $\mathrm{LDH})$ activity was significantly higher in the medium heavy body hens, from week 19 until the end of the investigation, activity values ranging between 1000 and 2500 IU/L. In the serum creatine kinase (CK) activity, from week 30 the brown hens showed significantly higher serum activities, data ranging from 2000 and 3000 IU/L. In contrast, for the serum amylase activity no particular trend was found.

Effects of genotype, age and bodyweigth on the serum biochemical parameters

Within the serum metabolites, a clearly genotype-determined difference was only detected for the serum uric acid concentration. Although the effects of age and genotype could not clearly be distinguished, merely genotype has been found to affect the serum creatinine, triglyceride, HDL cholesterol, calcium concentrations significantly.

Genotype classification on the basis of serum biochemical parameters

Since the statistical results clearly indicated that the white and brown type laying hens strongly differ in their metabolic and enzymatic properties, the classification of the genotypes was performed, purely on the basis of the serum biochemical parameters determined. In the discriminant analysis, $94.4 \%$ of the original grouped cases was correctly classified (Fig. 9), without any equivocal cases. Interestingly, when applying the stepwise method, a 77.1\% accuracy could be reached, by a model that only involved serum Ca, $\gamma$-GT, K, and creatinine parameters. 


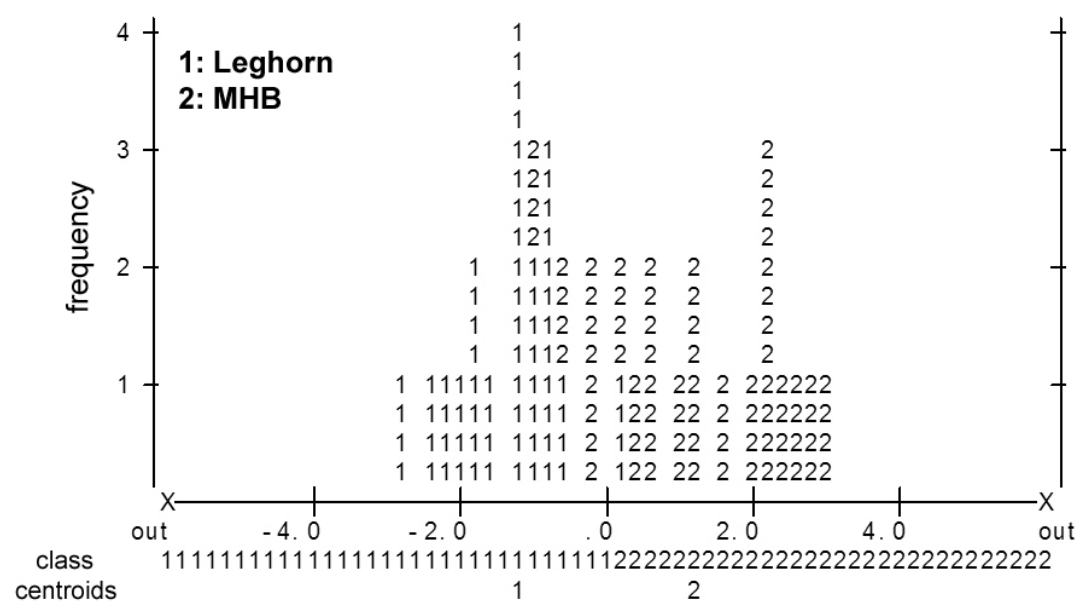

Fig. 9: Classification results between the two genotypes, entering all hematochemical parameters into the model (accuracy: 94.4\%; n=115) (Die Klassifiktion zwischen den zwei Genotypen, mit Hilfe aller Variablen; Genauigkeit: 94,4\%; n=115)

\section{Discussion}

Differences experienced between the genotypes may be attributed as expected, to the basic, genotype-associated differences. However, as far as the authors are aware, normal reference values for layers in such a wide age-interval have not been established before. Accordingly, data were merely compared within the two groups, and either interspecific comparisons, or those with other strains are reasoned by the relative lack of relevant data. However, the main focus was kept on the description of differences in the two strains' metabolic development.

\section{Serum metabolites and ions}

Serum nitrogenous compounds generally show large and well defined developmental courses along the ontogenic development, like it has been described in numerous instances in wild (starling: JURÁNI et al., 2004; white stork: MONTESINOS et al., 1997) and domestic (emu: COSTA et al., 1993; japanese quails: OZCELIK and OZBEY, 2004; roosters: STRAKOVA et al., 2001; turkey: SZABÓ et al., 2005) avian species. Laying hens of the present investigation are somewhat specific from this aspect, since the development before and during the egg production is rather different.

The early increasing trend (before the egg production) described for serum total protein and albumin, experienced until the beginning of the egg production (Fig. 3) is a well-known process, being strongly associated with the somatic growth (mainly muscle tissue hypertrophic growth), as described in turkey poults by VASICEK et al. (1991) and SZABÓ et al. (2005). Basically, the total improving process ranged within the normal values published for broilers (MELUZZI et al., 1992; SHAHIN and ELAZEEM, 2005) and for Thai chicken (SIMARAKS et al., 2004). In the background of these processes two, retaled main factors may stand: once the early growth is driven by growth hormone, which is known to increase serum protein levels, and as second, general anabolic processes, characteristic for this age interval, have identical effects in this regard. Although between the two genotypes there was practically no difference, the turning point of the serum metabolite concentrations (a peak) was paralleled by the total body crude protein content (Fig. 2). It may be thus assumed that within the 
overall somatic development the incorporation of dietary protein sources was only intensive latest until the age of 25 weeks. This was, furthermore, supported by the step up in the total body fat content at the same age (Fig. 2). Regarding creatinine, the three-peaked pattern, measured along the trial may be directly related to environmental factors. According to SZABÓ et al. (2005), the dietary protein load is sensitively reflected in the avian serum creatinine levels. From week seven, a 5\% reduction was applied in the dietary protein level, which was immediately detectable as well in the serum. Further concentration peaks detected at the ages 14 and 34 weeks age may be explained by either increased motory activity or expressed muscle hypertrophy. Accepting the direct dietary influence on the serum creatinine levels, the third peak may be induced by the $2 \%$ step in dietary crude protein content, applied in the layer feed (Table 1). Although three temporary peaks were measured, the general trend for creatinine was decreasing along the period investigated. As creatinine may be handled as an inactive end-product of the phosphocreatin breakdown in skeletal muscle, its serum levels are dependent (besides the dietary protein level) on the muscle proportion/mass within the body as well. Accordingly, the final reduction trend was consonant with the alteration of the total body crude protein content at the similar age (Fig. 2). Practically, from this age on, the fat deposition of birds increased markedly, which is a well known tendency in layer rearing (HORN, 1981; MACHAL et al., 1994; MACHAL and JERABEK, 2000).

In the lipid metabolites, triglyceride levels were basically not different, stronger between-genotype differences were only experienced after the drastic concentration step, at the age of 17 weeks. The data of the present study agree with the normal reference values for broilers (MELUZZI et al., 1992). The reason of the difference experienced by the dietary fat load (weeks 18-20) indicates a slower reaction of the medium heavy body hens to the increased dietary fat content (MACHAL and JERABEK, 2000). Since dietary fats are converted to serum lipoproteins by the liver, a slower, or less pronounced hepatic adaptation may be hypothesized behind the lower serum TG concentration in this period. This seems to be reflected as well in the continuously higher $\gamma$-GT activity values of these birds, referring to more sensitive hepatic defense against metabolic load.

The blood plasma cholesterol concentration between game birds is various and markedly lower than in domestic hens (STRAKOVA et al., 2001). The phenomenon, described for the cholesterol forms determined is one of the most interesting results of the present study. In a follow-up study on the forced moulting of Hy-Line Brown hens, the concentrations of cholesterol forms showed marked increases in a 12-day trial (ROMVÁRI et al., 2005). In an other Galliform, the turkey, along the entire rearing (age of 20 weeks) cholesterol concentration peaks were found when the energy balance tended to be negative, i.e. during moultings (SZABÓ et al., 2005). It is thus hypothesized that a negative energy balance increases serum total and HDL cholesterol concentration. The opposite may also be true: an improving metabolic/energetic condition, manifesting in the gradual increase of the total body fat content in both genotypes (Fig. 2) may be associated with lower serum HDL and total cholesterol concentrations. This may be supported by the fact that a step-up in the body fat content was shown at the same age when the decreasing cholesterol levels were measured. However, this relationship is not so direct, since for total cholesterol no marked correlation was found $\left(\mathrm{R}^{2}=-0.172, \mathrm{P}=0.078, \mathrm{n}=115\right)$ with the total body 
crude fat content, while HDL cholesterol concentration significantly and negatively correlated with the body fat content $\left(\mathrm{R}^{2}={ }^{-} 0.69, \mathrm{p}<0.001, \mathrm{n}=115\right)$. Interestingly, when the birds' body fat reserves tended to be depleted (after week 52), this was sensitively reflected by both cholesterol forms, again.

\section{Serum ion concentrations}

From the viewpoint of egg production, first calcium and as second, phosphorus is of major importance in the laying hen. It has to be added that our experimental design was merely applicable for the gross description of the calcium and phosphorus metabolism, since during egg production both substances' serum concentrations fluctuate according to the diurnal rhythm of egg production, but rather egg shell formation. The calcium levels of the two divergent bird populations were practically not different. As the dietary calcium content was fourfold in the production period then before it, this was directly reflected in the serum. The relatively quick increase of the dietary amount induced a concentration peak, while the latter, more balanced levels may be attributed to the active medullary bone-related calcium regulation (DACKE et al., 1993)

The explanation for the less different serum inorganic phosphorus concentrations may be that, as BOORMAN and GUNARATNE (2001) published, there is practically no relationship between eggshell weight and serum phosphorus concentrations. Accordingly, serum inorganic phosphorus concentrations fluctuated within physiological normal values (GARLICH et al., 1984) that became more balanced during the production period.

The reason for the measurement of the serum sodium concentration was basically not to detect differences between the to bird types, but to control the effects of possible dehydration. The well-known age-dependent concentration increase (in turkeys: VASICEK et al., 1991; SZABÓ et al., 2005) could be accurately detected, as well as its relationship with the increasing dry matter content of the body. Accordingly, a high positive correlation exists between the total body dry matter content and the serum sodium concentration.

\section{Serum enzymes}

Gamma glutamyl transaminase can be considered as one of the main hepatic enzymes; its presence in the blood referrs to some type of cell membrane leakage, though until a given level this is judged as normal or physiological. The values measured for the hens fluctuated within the physiological values, though in the entire trial period the MHB birds provided a higher value, which was more expressed during the intensification of the production. It may be thus hypothesized that the metabolic load of the brown birds was higher, or this genotype is more sensitive to environmental stimuli associated with egg production. Thus, the hepatic response to the high production was more expressed in the brown hybrids.

Alkaline phosphatase is a complex enzyme, related to secondary ossification, osteoblastic activity; moreover, it is produced in the intestinal brush border. In this regard PALO et al. (1995) reported an activity peak in broilers at the age of 2 weeks, corresponding to the exhaustion of the yolk sac as well as to the establishment of locomotory independence. An early peak, and the latter continuous activity reduction was moreover described by SZABÓ et al. (2005), along the entire rearing course of heavy weight turkeys. The experienced fact may be connected to a slowing-down in 
the ossification. Although in a still unknown way, the intestinal ALP isoform also shows an age-associated reduction, as also reported for White Pekin ducks by KING et al. (2000). Regarding ALP, it is widely known that egg-laying birds show a temporarily increased activity. When analyzing our dataset, a less pronounced but detectable plateau can be seen from week 12 until the $25^{\text {th }}$ week that was later diminished by the continued metabolic load of the birds. In the authors' opinion, the first, relatively intensive reduction is consonant with the well-known fact that the skeletal development of layers is nearly (over 90\%) finished at this age. This phase is followed by the muscle and fat tissues' building. The activity of lactate dehydrogenase (LDH) showed higher activity values in the medium heavy body hens in the entire egg production period. Since our analysis was limited to the determination of the basal total LDH activity, we can only suppose that the differences arose from the higher muscle proportion in the body. The higher creatine kinase (CK) activity described for the medium heavy bodied hens may also be associated with the total body muscle content. It is interesting that layers also provided increasing CK values after a defined point of keeping (i.e. week 30), since elevated CK activity is rather associated with muscle membrane damages. This is, however, mainly characteristic for meat type birds, such as broilers (MITCHELL et al., 1999) or turkeys (SZABÓ et al., 2005). In the authors' opinion, the genotype-dependent differences experienced in the present study may be a consequence of the higher muscularity of the medium heavy birds, leading ultimately to higher CK values. It has to be added, that although the differences were statistically different, those always remained within the physiological normal values (BRUGERE-PICOUX et al., 1987).

Amylase, as one of the key enzymes in the carbohydrate metabolism may occur in the serum both from the pancreatic source and the saliva, albeit our results concern the total activity. Basically, two characteristic phenomena were found for this enzyme. The first is an activity drop at the age of 12 weeks, possibly associated lower stress in this period. This may be supported by the activity drops measured as well for creatinine and CK at this period. The second is the significantly higher activity after this negative peak in the brown birds. The higher amylase activities in the medium heavy birds may reflect the higher feed intake, though amylase basically shows an ageassociated activity increase, which was detected in both genotypes (ROUTMAN et al., 2003).

\section{Classification on the basis of serum biochemical parameters}

The primary aim of the present study was to describe genotype-associated differences during the metabolic development of the laying hen populations, selected in divergent directions. Although statistical differences were detected in numerous hematochemical parameters, a single, determinant factor for an accurate classification could not be found in the frame of our study. Accordingly, a proper classification method was successfully - tested on the dataset. The obtained accuracy of $94.4 \%$ can be characterized as rather high. It is, however, interesting that the stepwise approach only handled Ca, $\gamma$-GT, K and creatinine as bases of classification. When relying on the results of the latter approach, the differences between the two divergent hybrides are mainly attributed to the above-mentioned four constituents. As far as the authors are aware, such results have not yet been published; therefore, the explanation of this classification is hypothetic. However, the four hematochemical constituents are associated to physiological properties in which the two hybrids are strongly different. 
In this context, the skeletal weight and the Ca metabolism may be connected, while creatinine may be associated with the muscle mass and the strongly related motory activity. As presented above, the metabolic load may compromise hepatic functions to different extents in the two birds, manifesting in differing sensitivity, as reflected by the serum levels of $\gamma$-GT. The physiological meaning of the finding regarding potassium is hardly explainable.

\section{Acknowlegdement}

The financial support of the Hungarian Research Fund (OTKA), project No. TS044743 is gratefully acknowledged.

\section{References}

BOORMAN, K.N.; GUNARATNE, S.P.:

Dietary phosphorus supply, egg-shell deposition and plasma inorganic phosphorus in laying hens. Br. Poult. Sci. 42 (2001), 81-91

BRUGERE-PICOUX, J.; BRUGERE, H.; BASSET, I.; SAYAD, N.; VAAST, J.; MICHAUX, J.M.: Clinical biochemistry in avian pathology. Value and limitations of enzyme assays in the laying hen. Rec. Med. Vet. 163 (1987), 1091-1099

COSTA, N.D.; MCDONALD, D.E.; SWAN, R.A.:

Age-related changes in plasma biochemical values of farmed emus (Dromaius novahollandiae). Aust. Vet. J. 70 (1993), 341-344

CROSS, K.E., DODDS, P.F., NOBLE, R.C., MCCARTNEY, R., CONNOR, K.: Effects of age and diet on the lipid content and composition of gallbladder bile, liver and serum in laying strains of hen. Br. Poult. Sci. 28 (1987), 577-584

DACKE, C.G.; ARKLE, S.; COOK, D.J.; WORMSTONE, I.M.; JONES, S.; ZAIDI, M.; BASCAL, Z.A.: Medullary bone and avian calcium regulation. J. Exp. Biol. 184 (1993), 63-88

DURMUS, I., ATASOGLU, C., MIZRKA, C., ERTAS, S., KAYA, M.: Effect of increasing zinc concentration in the diets of Brown parent stock layers on various production and hatchability traits. Arch. Tierz., Dummerstorf 47 (2004) 5, 483-489

GARLICH, J.; BRAKE, J.; PARKHURST, C.R.; THAXTON, J.P.; MORGAN, G.W.:

Physiological profile of caged layers during one production year, molt, and postmolt: egg production, egg shell quality, liver, femur, and blood parameters. Poult. Sci. 63 (1984) 2, 339-343

HESTER, P.Y.:

Impact of science and management on the welfare of egg laying strains of hens. Review. Poult. Sci. 84 (2005) 5, 687-696

HORN, P.:

Manual of Poultry Breeding. In Hungarian. Budapest, Hungary 1981.

JURÁNI, M.; VYBOH, P.; ZEMAN, M.; LAMOSOVA, D.; KOSTAL, L.; BLAZICEK, P.:

Post-hatching dynamics of plasma biochemistry in free-living European starlings (Sturnus vulgaris). Comp. Biochem. Physiol. 138 (2004) 1, 89-95

KING, D.E.; ASEM, E.K.; ADEOLA, O.:

Ontogenetic development of intestinal digestive functions in White Pekin ducks. J. Nutr. 130 (2000) 1, 57-62

MACHAL, L.; INGR, I. ; KALOVA, J. ; ABEK, S.J. :

The dependence of the hatchability, laying and egg weight on the egg cholesterol level and cholesterol andtotal lipids concentration in the blood plasma in hens of laying strains. Arch. Tierz., Dummerstorf 37 (1994) 5, 567-575

MACHAL, L.; JERABEK, S. :

Changes in plasma lipaemia, glycaemia and uremia caused by the negative interaction of the genotype and environment during the laying period of hens of initial lines of laying hybrids. Arch. Tierz., Dummerstorf 43 (2000) 1, 79-86

MELUZZI, A.; PRIMICERI, G.; GIORDANI, R.; FABRIS, G.:

Determination of blood constituents reference values in broilers. Poult. Sci. 71 (1992) 2, 337-345

MIELENZ, N.; SCHMUTZ, M.; SCHÜLER, L.:

Untersuchungen zur Mortalität von Legehennen gehalten in Einzel- und Gruppenkäfigen. Arch. Tierz., Dummerstorf 48 (2005) 4, 404-411

MITCHELL, M.A.; SANDERCOCK, D.A.; HUNTER, R.R.; CARLISLE, A.J.: 
Skeletal muscle damage following halothane anaesthesia in the domestic fowl: plasma biochemical responses. Res. Vet. Sci. 67 (1999) 1, 59-64

MONTESINOS, A.; SAINZ, A.; PABLOS, M.V.; MAZZUCHELLI, F.; TESOURO, M.A.:

Hematological and plasma biochemical reference intervals in young white storks. J. Wildlife Dis. 33 (1997) 3, 405-412

MUIR, W.M.:

Indirect selection for improvement of animal well-being. p. 247-256. In Poultry Breeding and Biotechnology Ed. WM MUIR and S AGGREY. CABI Press Cambridge 2003.

NURGIARTININGSIH, V.; MIELENZ, N.; PREISINGER, R.; SCHMUTZ, M.; SCHÜLER, L.:

Genetic parameters for egg production and egg weight of laying hens housed in single and group cages. Arch. Tierz., Dummerstorf 45 (2002) 5, 501-508

OZCELIK, M., OZBEY, O.:

The effect of the high environmental temperature on some blood parameters and the laying performance of Japanese quails with different body weights (short communication). Arch. Tierz., Dummerstorf 47 (2004) 1, 93-98

PALO, P. E.; SELL, J. L.; PIQUE, F. J.; VILASECA, L.; SOTO-SALANOVA, M. F.:

Effects of nutrient restriction on broiler chickens 2. Performance and digestive enzyme activities. Poult. Sci. 74 (1995) 9, 1470-1483

RODENBURG, T.B.; KOENE, P.; SPRUIJT, B.M.:

Reaction to frustration in high and low feather pecking lines of laying hens from commercial or seminatural rearing conditions. Behav. Processes. 65 (2004) 2, 179-188

ROMVÁRI, R.; SZABÓ, A.; ANDRÁSSY-BAKA, G.; SÜTÖ, Z.; MOLNÁR, T.; HORN, P.:

Tracking forced moult by computer tomography and serum biochemical parameters in laying hens. Arch. Geflügelkd. 69 (2005) 6, 245-251

ROUTMAN, K.S.; YOSHIDA, L.; FRIZZAS DE LIMA, A.C.; MACARI, M.; PIZAURO, JR. J.M.: Intestinal and pancreas enzyme activity of broilers exposed to thermal stress Rev. Bras. Cienc. Avic. 5 (2003) 1, 23-27

SHAHIN, K.A.; ELAZEEM, F.A.:

Effect of breed, sex and diet and their interactions on carcass composition and tissue weight disribution of broiler chickens. Arch. Tierz., Dummerstorf 48 (2005) 6, 612-626

SIMARAKS, S.; CHINRASRI, O.; AENGWANICH, S.:

Hematological, electrolyte and serum biochemical values of the Thai indigenous chickens (Gallus domesticus) in northeastern Thailand. Songklanakarin J. Sci. Technol. 26 (2004) 3, 425-430

SPSS 10 for Windows (1999). SPSS Inc. Chicago, IL, USA.

STRAKOVA, E.; VITULA, F.; SUCHY, P.; VECEREK, V.; SKALOUD, J.:

Cholesterol concentration in yolks and blood plasma in five species of game birds (short communication). Arch. Tierz., Dummerstorf 44 (2001) 3, 339-343

STRAKOVA, E.; SUCHY, P.; VECEREK, V.; MACHAL, L.:

The variation in amino acid level in the blood plasma of breeding rooseters during sexual maturation. Arch. Tierz., Dummerstorf 45 (2002) 3, 279-285

STRUELENS, E.; TUYTTENS, F.A.; JANSSEN, A.; LEROY, T.; AUDOORN, L.; VRANKEN, E.; DE BAERE, K.; ODBERG, F.; BERCKMANS, D.; ZOONS, J.; SONCK, B.:

Design of laying nests in furnished cages: influence of nesting material, nest box position and seclusion. Br. Poult. Sci. 46 (2005) 1, 9-15

SUCHY, P.; STRAKOVA, E.; CHLOUPEK, J.; SUCHY, P.:

The dynamics of acid-base balance of blood in hens fed on the same diets during laying period. Arch. Tierz., Dummerstorf, 40 (1997) 4, 371-379

SZABÓ, A.; MÉZES, M.; HORN, P.; SÜTÖ, Z.; ROMVÁRI, R.:

Developmental dynamics of some blood biochemical parameters in the growing turkey (Meleagris gallopavo). Acta Vet. Hung. 53 (2005) 4, 397-409

VASICEK, L.; SHWENDENWEIN, I.; VOILL, S.:

Chemical blood analysis to establish standard values in turkeys of different ages. Deutsch. Tierärztl. Wochenschr. 98 (1991) 4, 126-129

Received: 2005-11-14

Accepted: 2006-05-31

Corresponding Author

JÓZSEF GYENIS

University of Kaposvár, Faculty of Animal Science,

7400, KAPOSVÁR, Guba S. u. 40.

HUNGARY

E-Mail: jgyenis@hu.provimi.com 